DOI : https://doi.org/10.31186/terra.3.2.32-38

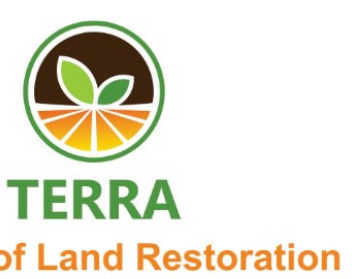

\title{
Analysis of the Level of Erosion Hazard By Using Remote Sensing and Geographic Information System in the Sub-Watershed of Rindu Hati
}

\author{
Prayogi Dhuha Brahmanto ${ }^{1}$, Bambang Sulistyo ${ }^{1 *}$, M. Faiz Barchia ${ }^{1}$ \\ ${ }^{1}$ Soil Science Department, University of Bengkulu (Corresponding author) \\ e-mail: bsulistyo@unib.ac.id
}

\begin{abstract}
Rindu Hati sub-watershed is located in District of Central Bengkulu, Bengkulu Province, that has flat until montainous topography with various slope and annual rainfall up to 4,032 $\mathrm{mm}_{\text {year }}{ }^{-1}$ which possible causes erosion. This research was aimed to analyze soil erosion at Rindu Hati sub-watershed based on the Universal Soil Loss Equation formula, using remote sensing imagery data and by applying GIS technique. USLE method were uses five parameters, those were length and slope factor, rainfall erosivity factor, crop management factor and land conservation, and soil erodibility factor. An overlay analysis has been conducted to obtain the erosion. Then, the result is overlaid with soil depth map to get the level of erosion hazard, which is classified into: very light, light, moderate, heavily, and very heavily. The results showed that the total erosion was 12,410,650.59 tons $\mathrm{ha}^{-1}$ year ${ }^{-1}$, while its level of erosion hazard were very light (15 tons $\mathrm{ha}^{-1}$ year ${ }^{-1}$ ) covering an area of 2,983 ha spreading over community agricultural areas and forest areas, the rate of light erosion (> 15-60 tons $h^{-1}$ year ${ }^{-1}$ ) has the largest area of covering an area of 10,410.05 ha which scattered in plantation areas having flat topography, moderate erosion rates $\left(>60-180\right.$ tons ha $^{-1}$ year $\left.{ }^{-1}\right)$ of 1,317.33 ha spread over land areas with shrub land use and relatively flat topography, heavily erosion rates (> 180480 tons $\mathrm{ha}^{-1}$ year ${ }^{-1}$ ) covering $1,735.48$ ha spread over land with shrub land use but has a hilly topography and very heavily erosion rates (> 480 tons ha $a^{-1}$ year ${ }^{-1}$ ) covering 2,700.42 ha located in the mining area. Erosion potential rate mapping will be very helpful in determining good and appropirate land management and conservation in the study area.
\end{abstract}

Keywords: erosion, erosion hazard, GIS, USLE, watershed

\section{INTRODUCTION}

Watershed degradation has been accelerated by increasing utilization of natural resources as a result of population growth, economic development, policies that do not favor natural resources conservation, and the lack of awareness and participation of the community in the context of natural resource use (Sonapasma, 2010)

The Agency for Watershed and Protection Forest Management of Ketahun (2013) stated that there has been a change of function of the forest area into a mining and plantation area in the Rindu Hati sub-watershed area, the upstream part of the Bengkulu watershed. The conversion of the forest area has led to an increase in degraded land in the upstream area of the Bengkulu watershed with a critical area of $363,583.68$ ha. The degraded land is divided into slightly degraded of $207,414.75$ ha $(57.05 \%)$, degraded of 149,587.52 (41.14\%) and highly degraded of $6,581.41$ ha $(1.81 \%)$, while the degraded land outside the forest area reaches $866,176.80$ ha consisting of slightly degraded of 295,662.01 ha (34.13\%), degraded of 477,113 ha (55.08\%), and highly degraded of 93,401.79 ha (10.78\%).

One of the causes of the increase in the degraded land is the erosion that occurs on open land that has little vegetation on it as a ground cover. Erosion itself is a process of loss or erosion of soil or parts of land from a place that is transported by water or wind to another place. The eroded land transported by surface runoff will be deposited in a place where water flow slows down such as rivers, irrigation channels, reservoirs, lakes or river mouths. This will have an impact on silting rivers, resulting in more frequent floods in the rainy season and drought in the dry season (Arsyad, 2010) 
To get erosion data, it is necessary to predict soil erosion from a model. Erosion is predicted from a model because to get actual erosion data requires a lot of time, energy and cost. Sulistyo (2011) states that one of the erosion prediction models that is widely used in various countries, including Indonesia, is USLE. USLE (Universal Soil Loss Equation) is an erosion prediction model that is widely used in various countries, because the model is easy to manage, relatively simple and the number of inputs or parameters needed is relatively small compared to other erosion prediction models (Sulistyo, 2011).

In the USLE, there are 6 factors used including erosivity factors (rainfall), soil erodibility factors, slope length factors, slope steepness factors, vegetation cover factors and plant management, and conservation factors soil (Manik et al., 2013). To be able to analyze and calculate erosion can utilize Geographic Information System (GIS) technology. This technology can map and describe the physical condition of the research area spatially. These physical conditions are the parameters that cause erosion. By utilizing GIS, this method can determine, calculate, and show visually areas that need conservation (Santoso, 2014). Based on the description above, this study was conducted to analyze the level of erosion hazard in the Rindu Hati sub-watershed area.

\section{MATERIAL AND METHOD}

\section{Location of the research}

This research was conducted in the Rindu Hati sub-watershed in the Central Bengkulu area with an area of 19,147 ha, which was conducted from August 2019 to November 2019.

\section{Data Collection}

Data needed in conducting this research is erosivity map, topographic map, soil and land unit map and land use map. Before the research activities are carried out, a research plan is first carried out, a literature review, procurement of image maps, land use maps, topographic maps and rainfall data for the Rindu Hati sub-watershed. The analysis is done by converting soil type maps into K (erodibility) map, rainfall data into erosivity map (R), topographic maps into slope map and land use map into vegetation map and soil conservation technique (CP).

\section{Data Analysis}

The method of assessing the level of erosion hazard is carried out by overlaying or combining several maps into a unitary and scoring method (assessment).
Erosivity score

$$
\mathbf{R}_{\mathbf{m}}=6,119\left(\operatorname{Rain}_{\mathbf{m}}\right)^{1.21} \mathbf{X}\left(\mathbf{D a y s}_{\mathrm{m}}\right)^{-0.47} \mathbf{X}\left(\max \mathbf{P}_{\mathrm{m}}\right)^{0,53}
$$

Where:

$$
\begin{array}{ll}
\mathrm{R}_{\mathrm{m}} & =\text { rain erosivity } \\
\text { Rain }_{\mathrm{m}} & =\text { monthly average rainfall (in cm) } \\
\text { Days }_{\mathrm{m}} & =\text { average number of rainy days in one } \\
& \text { month }
\end{array}
$$

Max $\mathrm{P}_{\mathrm{m}}=$ average maximum rainfall in the month (cm)

\section{Erodibility score}

Soil erodibility is the sensitivity of soil to erosion, the higher the erodibility value of a soil, the easier it is to erode. The soil erodibility value obtained from the calculation of the erodibility value using the equation as foloows (Wischmeier et al., 1971) :

$$
\begin{aligned}
100 \mathrm{~K}= & \begin{aligned}
1,292\left[2,1 \mathrm{M}^{1,14}\left(10^{-4}\right)(12-\mathrm{a})+3,25(\mathrm{~b}-2)+\right. \\
2,5(\mathrm{c}-3)]
\end{aligned} \\
\mathrm{M}= & \begin{array}{l}
\text { Percentage of very fine sand and dust } \\
\text { (diameters from } 0.1 \text { to } 0.05 \text { and } 0.05 \text { to }
\end{array} \\
& 0.02 \mathrm{~mm}) \times(100-\text { percentage of clay) } \\
\mathrm{a}= & \text { percentage of organic matter } \\
\mathrm{b}= & \text { value of soil structure } \\
\mathrm{c}= & \text { value of soil permeability }
\end{aligned}
$$

LS score

L Factor

Where :

$\mathrm{La}=$ actual slope length (in $\mathrm{m}$ )

$\mathrm{m}=0.5$

\section{S Factor}

For slopes $<25 \%$ the factor $\mathrm{S}$ value uses the values as presented in Table 1 .

Table 1. Slope scores (S)

\begin{tabular}{ccc}
\hline Class & $\begin{array}{c}\text { Slope } \\
\mathbf{( \% )}\end{array}$ & Sscore \\
\hline I & $0-3$ & 0.1 \\
II & $>3-8$ & 0.5 \\
III & $>8-15$ & 1.4 \\
IV & $>15-25$ & 3.1 \\
\hline
\end{tabular}

Source : RTKRHL modification, 2009 
For slopes $>25 \%$, it uses the Gremory formulas:

$$
\left.\mathrm{LS}=\mathrm{C} \times \operatorname{Cos}\left(\mathrm{S}_{\mathrm{d}}\right)^{1.503} \times \underset{2.249}{\{0,5}\right\} \sin \left(\mathrm{S}_{\mathrm{d}}\right)^{1.249}+\sin \left(\mathrm{S}_{\mathrm{d}}\right)
$$

Where :

$$
\begin{array}{ll}
\mathrm{S}_{\mathrm{d}} & =\text { slope in degrees } \\
\mathrm{C} & =\text { constant }(34.7046) \\
\mathrm{M} & =0.5
\end{array}
$$

CP score

The value of plant management and soil conservation is obtained from the land use map and is matched with the value of the results of research that has been carried out as presented in Table 2 and Table 3 .

Table 2. C scores (Crop management)

\begin{tabular}{lr}
\hline \multicolumn{1}{c}{ Type of plant } & C scores \\
\hline Rice fields & 0.01 \\
Upland rice (dry land) & 0.53 \\
Corn & 0.64 \\
Soybean & 0.4 \\
Peanut & 0.4 \\
Cassava & 0.7 \\
Talas & 0.7 \\
Sweet potatoes & 0.4 \\
Cotton & 0.7 \\
Tobacco & $0.46^{*}$ \\
Chilles, onions, other & \\
vegetables & 0.7 \\
Coffee & \\
Chocolate & 0.6 \\
Coconut & 0.8 \\
Palm oil & 0.7 \\
Rubber & 0.5 \\
Empty land, not procesed & 0.95 \\
Empty land, cultivated & 1.0 \\
Unditurbed bush & 0.01 \\
Forest undisturbed, a little bit & 0.005 \\
\hline
\end{tabular}

After calculating and assessing erosivity, erodibility, length and slope factors and crop management and soil conservation techniques, the erosion rate (A) can be obtained. Estimated amount of erosion can be determined by the USLE method according to Wischmeier and Smith (1978) that is :

$$
\begin{array}{ll}
\text { Where : } & \\
\mathrm{A} & =\text { amount of eroded land (ton / } \mathrm{h} / \text { year) } \\
\mathrm{R} & \text { = erosivity factor } \\
\mathrm{K} & \text { = soil erodibility factor } \\
\mathrm{L} & \text { = slope length factor } \\
\mathrm{S} & \text { = slope factor } \\
\mathrm{C} & \text { = factor of land cover vegetation } \\
\mathrm{P} & \text { = factor of soil conservation }
\end{array}
$$

\begin{tabular}{|c|c|c|c|c|c|}
\hline \multirow{4}{*}{$\begin{array}{c}\text { Soil } \\
\text { Depth } \\
\text { (cm) }\end{array}$} & \multicolumn{5}{|c|}{ Class erosion } \\
\hline & I & II & III & IV & $\mathbf{V}$ \\
\hline & \multicolumn{5}{|c|}{ Erosion (ton/ha/year) } \\
\hline & $<15$ & $15-60$ & $\begin{array}{l}60- \\
180\end{array}$ & $\begin{array}{c}180- \\
480\end{array}$ & $>480$ \\
\hline $\begin{array}{l}\text { Deep } \\
>90\end{array}$ & $0-\mathrm{VL}$ & I-L & II-M & III-H & $\begin{array}{l}\text { IV- } \\
\text { VH }\end{array}$ \\
\hline $\begin{array}{l}\text { Moderate } \\
60-90\end{array}$ & $\mathrm{I}-\mathrm{L}$ & II-M & III-H & $\begin{array}{l}\text { IV- } \\
\text { VH }\end{array}$ & $\begin{array}{l}\text { IV- } \\
\text { VH }\end{array}$ \\
\hline $\begin{array}{l}\text { Shallow } \\
30-90\end{array}$ & II-M & III-H & $\begin{array}{l}\text { IV- } \\
\text { VH }\end{array}$ & $\begin{array}{l}\text { IV- } \\
\text { VH }\end{array}$ & $\begin{array}{l}\text { IV- } \\
\text { VH }\end{array}$ \\
\hline $\begin{array}{l}\text { Very } \\
\text { Shallow } \\
<30\end{array}$ & III-H & $\begin{array}{l}\text { IV- } \\
\text { VH }\end{array}$ & $\begin{array}{l}\text { IV- } \\
\text { VH }\end{array}$ & $\begin{array}{l}\text { IV- } \\
\text { VH }\end{array}$ & $\begin{array}{l}\text { IV- } \\
\text { VH }\end{array}$ \\
\hline
\end{tabular}

Table 3. P scores (soil conservation technique)

\begin{tabular}{lc}
\hline \multicolumn{1}{c}{ Soil Conservation Technic } & P scores \\
\hline Bench terrace, good & 0.04 \\
Bench terrace, moderate & 0.15 \\
Bench terrace, bad & 0.40 \\
Traditional terrace & 0.35 \\
Plant the slope contour 1-3\% & 0.4 \\
Plant the slope contour 3-8\% & 0.5 \\
Plant the slope contour $8-15 \%$ & 0.6 \\
Plant the slope contour $15-25 \%$ & 0.8 \\
Plant the slope contour $>25 \%$ & 0.9 \\
\hline
\end{tabular}

Source : RTkRHL modification, 2009

Then the erosion map is overlayed to soil depth map which is then classified into the erosion hazard level. An assessment of the rate of erosion is presented in Table 4.

Table 4. Assessment of the erosion rate of the model predictions USLE

Source : RTKRHL, 2009

Remarks : $\quad 0-\mathrm{VL}=$ Very light; I-L $=$ Light

II-M $=$ Moderate

III-H = Heavily

IV-VH = Very Heavily 


\section{RESULT AND DISCUSSION}

Erosivity score

The largest erosivity value is 4,032 with an area of 200 ha or $(1.045 \%)$ spread in the area of Taba Teret Village, Taba Baru Village, Surau Village and Rindu Hati Village (Table 5 and Figure 1).

Table 5. The Area and their percentage for each erosivity value in the Rindu Hati sub-watershed

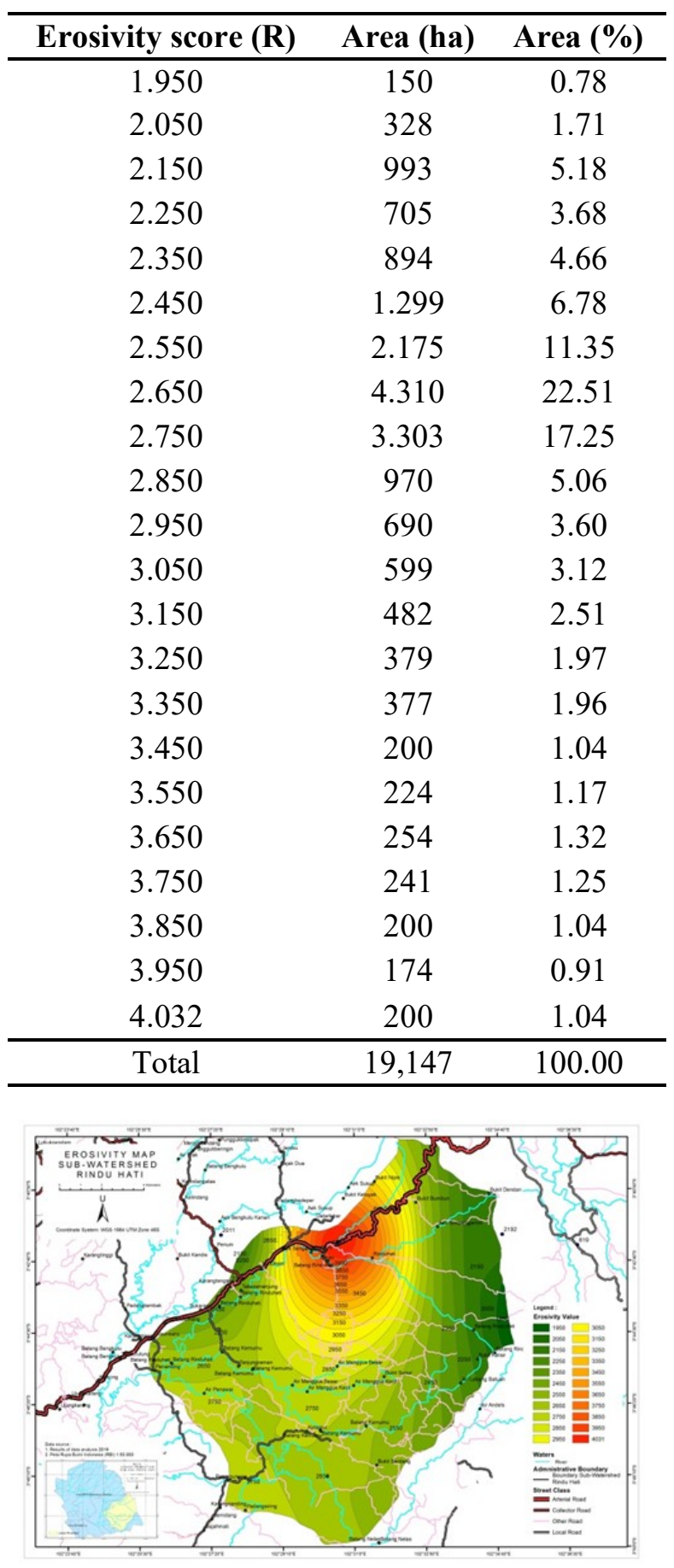

Figure 1. Erosivity Map of Rindu Hati sub-watershed

\section{Erodibilityscore}

Soil types in the Rindu Hati sub-watershed are dominated by inceptisol soil types, while the smallest $\mathrm{K}$ value is 0.05 with an area of $1,322.55$ ha or $6.90 \%$ of the total area. Then Ultisols soil type has an erodibility value of 0.3 and has an area of 149.74 ha or $0.78 \%$ of the total area. The soil erodibility value in the Rindu Hati sub-watershed ranges from 0.05 to 0.42 . With an average erodibility value of 0.23 included in the medium category, it can be concluded that the Rindu Hati sub-watershed has a soil sensitivity to erosion that is neither too low nor too high (Figure 2 and Table 6).

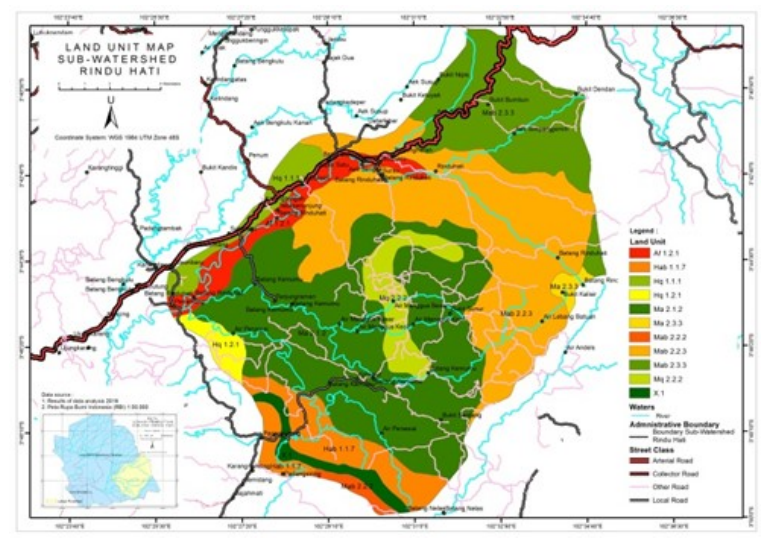

Figure 2. Erodibility Map of Rindu Hati sub Watershed

Table 6. Soil type and Erodibility Value in the RinduHati sub-watershed

\begin{tabular}{lllc}
\hline Land Unit & $\begin{array}{c}\text { Type of } \\
\text { Soil }\end{array}$ & K Scores Area (ha) \\
\hline Af 1.2.1 & Inceptisol & 0.28 & 909.60 \\
Hab 1.1.7 & Inceptisol & 0.05 & $1,322.55$ \\
Hq 1.1.1 & Inceptisol & 0.31 & 605.28 \\
Hq 1.2.1 & Inceptisol & 0.28 & 304.01 \\
Ma 2.1.2 & Inceptisol & 0.20 & $6,518.51$ \\
Ma 2.3.3 & Inceptisol & 0.30 & 132.18 \\
Mab 2.2.2 & Ultisol & 0.30 & 149.74 \\
Mab 2.2.3 & Inceptisol & 0.25 & $5,301.75$ \\
Mab 2.3.3 & Inceptisol & 0.42 & $2,710.89$ \\
Mq 2.2.2 & Inceptisol & 0.08 & 826.33 \\
X.1 & Inceptisol & 0.10 & 364.93 \\
\cline { 1 - 1 } & Total & 19.147 \\
\hline
\end{tabular}

Source : Data analysis, 2019 
LS score

Length and slope factors are obtained from slope maps created using 25 meter contour interval data. The slope class of the Rindu Hati sub-watershed is divided into six classes, namely flat (0-3\%), slightly flat $(>3-8 \%)$, sloping $(>8-15 \%)$, rather steep $(>15-$ $25 \%)$, steep $(>25-45 \%)$ and very steep $(>45 \%)$. The slope map can be seen in Figure 3, while their area is presented in Table 6 .

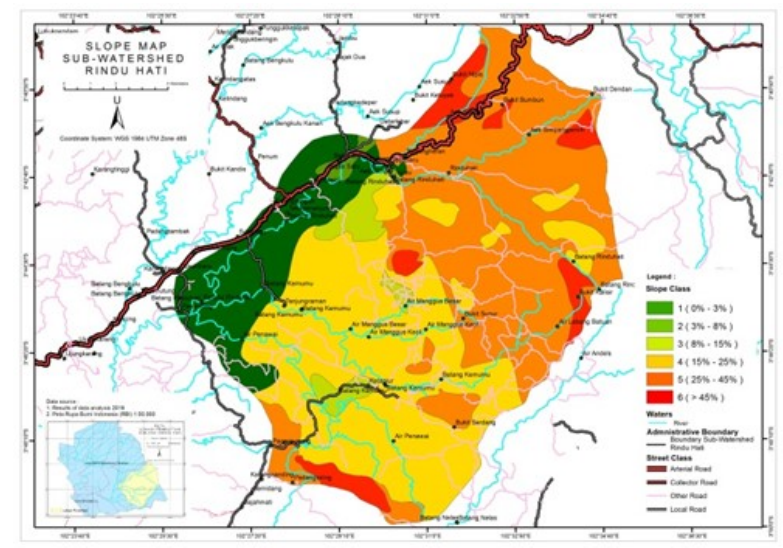

Figure 3. Slope Map of Rindu Hati sub-watershed

Table 6. The area for each Slope and LS Score

\begin{tabular}{cccrc}
\hline Class & $\begin{array}{c}\text { Slope } \\
\text { (\%) }\end{array}$ & $\begin{array}{c}\text { LS } \\
\text { scores }\end{array}$ & $\begin{array}{c}\text { Area } \\
\text { (ha) }\end{array}$ & $\begin{array}{c}\text { Area } \\
(\%)\end{array}$ \\
\hline I & $0-3$ & 0.1 & $2,648.18$ & 13.83 \\
II & $>3-8$ & 0.6 & 145.94 & 0.76 \\
III & $>8-15$ & 2.0 & 699.09 & 3.65 \\
IV & $>15-25$ & 12.0 & $7,105.04$ & 37.10 \\
V & $>25-45$ & 14.3 & $7,444.90$ & 38.88 \\
VI & $>45$ & 19.7 & $1,107.25$ & 5.78 \\
\hline \multicolumn{7}{c}{ Total } & 19.147 & 100 \\
\hline
\end{tabular}

Source : Data analysis, 2009

\section{CP score}

The Rindu Hati sub-watershed consists of 9 types of land use, namely forest, open land, rubber, coffee, rice fields, oil palm, scrub, mining and settlement. Land use in the Rindu sub-watershed is dominated by forests with a lot of litter and includes coffee plantations with an area of 13,333.716 $(69,63 \%)$ ha, but for coffee plantations that are not included in the forest has an area of 4,658 ha $(0.024 \%)$ and for the lowest land use namely shrubs covering an area of $2,034.528$ ha $(10.625 \%)$, oil palm plantations covering $1,295.193$ ha $(6.764 \%)$, rubber plantations covering an area of 40,321 ha $(0,211 \%)$, open land
335,372 ha $(1.751 \%)$, coal mining covering an area of $1,372.476$ ha $(7.168 \%)$, settlements covering 221,152 ha $(1.155 \%)$. Map of land use in the Rindu Hati sub-watershed can be seen in Figure 4. The value of plant management $(\mathrm{C})$ and soil conservation $(\mathrm{P})$ factors can be seen in Table 7 .

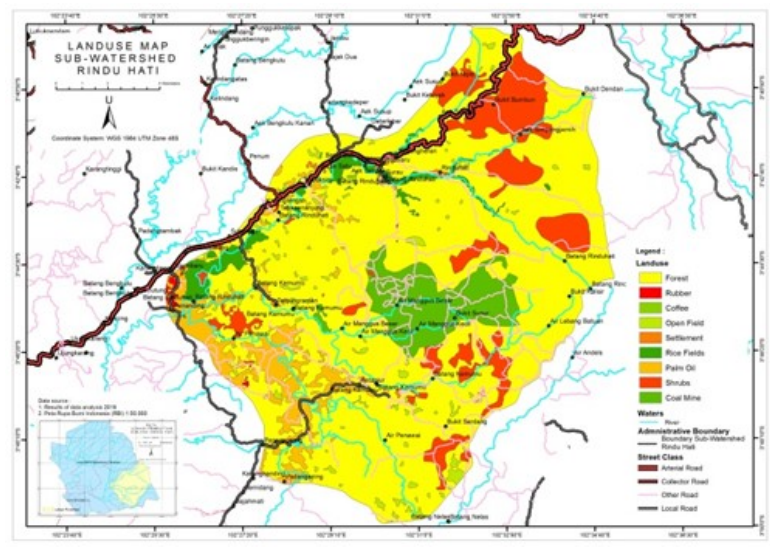

Figure 4. Landuse Map of Rindu Hati subwatershed

Tabel 7. Extensive data for each CP Value of Land

\begin{tabular}{lc}
\hline Landuse & CP scores \\
\hline Forest & 0,001 \\
Open field & 0,95 \\
Rubber & 0,4 \\
Coffee & 0,24 \\
Rice filed & 0,0035 \\
Young plam oil & 0,3 \\
Palm oil & 0,45 \\
Shrubs & 0,01 \\
Coal mine & 1 \\
Settlement & 1 \\
\hline
\end{tabular}

Source: RTkRHL, 2019

Soil Depth

The soil depth in the Rindu Hati subwatershed is dominated by a depth of $60-90 \mathrm{~cm}$. The soil depth table is presented in Table 8 and the soil depth map of the Rindu Hati sub-watershed can be seen in Figure 5

Tabel 8. Soil depth

\begin{tabular}{ccc}
\hline $\begin{array}{c}\text { Soil Depth } \\
(\mathbf{c m})\end{array}$ & Area (Ha) & Area (\%) \\
\hline$>90$ & 4,615 & 24.1 \\
$60-90$ & 14,531 & 75.9 \\
\hline Total & 19,147 & 100.0 \\
\hline
\end{tabular}

TERRA,3(2), 32-38 (2020) 


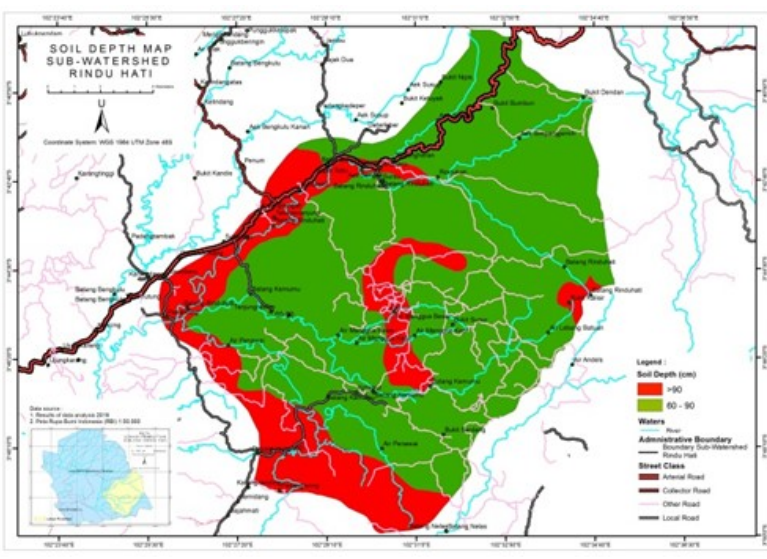

Figure 5. Soil Depth Map of Rindu Hati subWatershed

\section{The Level of Erosion Hazard}

The role of GIS in analyzing the level of erosion hazard map is in the overlay process by combining each erosion factor into new data with more complete attributes. From the overlay results there will be attribute table that has the value fields of $R$, $\mathrm{K}$, LS, C and $\mathrm{P}$ which then used for the erosion calculation by multiplying the erosion parameters and then overlaying it again with a soil depth map so that a map of erosion hazard level is obtained (Figure 6). From the results of this calculation an erosion hazard classification of five classes was carried out, and it is presented in Table 9.

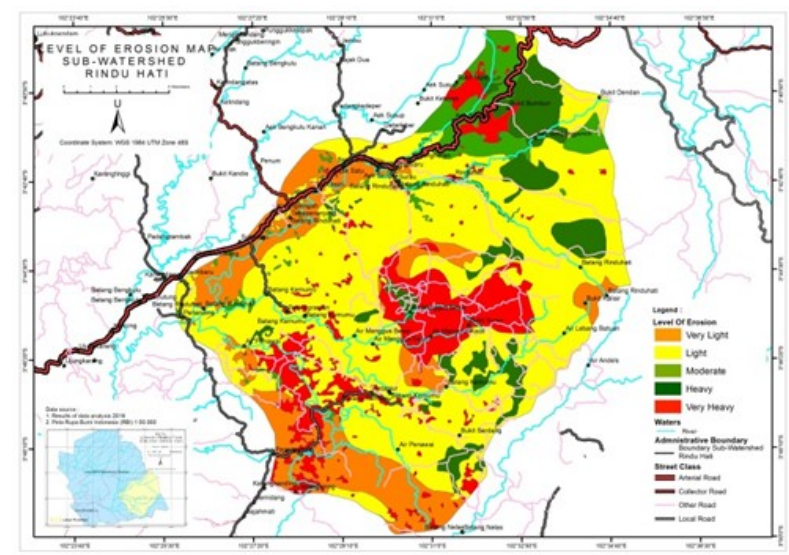

Figure 6. The Level of Erosion Hazard of Map Rindu Hati sub-watershed

The erosion hazard class in the Rindu Hati sub-watershed consists of 5 classes: very light, light, moderate, heavily and very heavily. Based on the calculation, the amount of land lost due to erosion is $12,410,650.59$ tons $\mathrm{ha}^{-1}$ year $^{-1}$. The very light erosion class has an area of $2,983.11$ ha $(9.06 \%)$, the light erosion class has the largest area of 10,410.05 ha $(54.37 \%)$, the moderate erosion class is $1,317.33$ ha $(14.1 \%)$, a heavily erosion class of $1,735.48$ ha $(15.58 \%)$ and a very heavily erosion class of $2,700.42$ ha $(6.88 \%)$ The mining area has a large erosion value, this is because in mining activities the process is carried out soil dredging will change the contour of the soil so that it is cause faster and more eroded.

Table 9. Level of Erosion

\begin{tabular}{|c|c|c|c|}
\hline $\begin{array}{l}\text { Erosion Total } \\
\left(\text { ton }^{-1} \mathrm{a}^{-1} \text { year }^{-1}\right)\end{array}$ & $\begin{array}{l}\text { Level of } \\
\text { Erosion }\end{array}$ & $\begin{array}{c}\text { Area } \\
\text { (ha) }\end{array}$ & $\begin{array}{c}\text { Area } \\
(\%)\end{array}$ \\
\hline$<15$ & $\begin{array}{l}\text { Very } \\
\text { Light }\end{array}$ & 2,983 & 9.06 \\
\hline$>15-60$ & Light & $10,410.05$ & 54.37 \\
\hline$>60-180$ & Moderate & $1,317.33$ & 14.1 \\
\hline$>180-480$ & Heavily & $1,735.48$ & 15.58 \\
\hline$>480$ & $\begin{array}{l}\text { Very } \\
\text { Heavily }\end{array}$ & $2,700.42$ & 6.88 \\
\hline Total & & 19.147 & 100 \\
\hline
\end{tabular}

Source : Data analsys, 2019

\section{CONCLUSION}

Rindu Hati sub-watershed has a light to very heavily erosion rate. Land lost due to erosion ranged from 0.01 tons ha ${ }^{-1}$ year $^{-1}$ to $23,146.68$ tons ha $^{-1}$ year ${ }^{-1}$ with a very light erosion rate ( 15 tons $\mathrm{ha}^{-1}$ year $\left.^{-1}\right)$ having an area of 2,983 ha spread over community agricultural areas and forest areas, the rate of light erosion $\left(>15-60\right.$ tons ha $^{-1}$ year $\left.^{-1}\right)$ has the largest area of $10,410.05$ ha spread over plantations that have flat topography, moderate erosion rates $(>60-180$ tons ha $^{-1}$ year ${ }^{-1}$ ) of $1,317.33$ ha spread over land area with shrub land use and relatively flat topography, heavily erosion rate ( $>180-480$ tons $\mathrm{ha}^{-1}$ year $\left.^{-1}\right)$ of $1,735.48$ ha spread over land area with shrub land use but have topography hilly and very heavily erosion rate $\left(>480\right.$ tons ha $^{-1}$ year $\left.^{-1}\right)$ has an area of $2,700.42$ ha located in the coal mining area. The mining area has a large erosion value because in mining activities a dredging process is carried out which will change the contours of the soil so that it is cause faster and more eroded.

\section{References}

Abdurachman, A. (1989). Rainfall Erosivity and Soil Erodibility in Indonesia: Estimation and Variation 
with Time. Thesis Doctor. Faculty of Agricultural Sciences, Ghent, Belgium.

Asdak, C. (2010). Hidrologi dan Pengelolaan Daerah Aliran Sungai. Gadjah Mada University Press, Yogyakarta. (in Indonesian)

Bols, P.L. (1978). The Iso-Erodent Map of Java and Madura. Belgian Technical Asisitance Project ATA 105 Soil Research Institute, Bogor.

Balai Pengelolaan Daerah Aliran Sungai dan Hutan Lindung Ketahun. (2013). Profil Kondisi Daerah Aliran Sungai Air Bengkulu, Kota Bengkulu. (in Indonesian)

Direktorat Jenderal Reboisasi dan Rehabilitasi Lahan, Departemen Kehutanan. (2009). Pedoman Penyusunan Rencana Teknik Lapangan Rehabilitasi Lahan dan Konservasi Tanah Daerah Aliran Sungai. Balai Pengelolaan Daerah Aliran Sungai Jeneberang-Walanae,Makassar.(in Indonesian)

Fatmagara, M. Adi. (2013). Pemanfaatan Citra PJ Multitemporal untuk Kajian Tingkat Bahaya Erosi (Kasus di Sub DAS Karang Mumus, Kalimantan Timur). Skripsi, UGM, Yogyakarta.(in Indonesian)

Gee, G. W. \& Bauder, J.W. (1986). Particle size analysis. p.383-411. In: A. Klute (Ed.). Methods of Soil Analysis (Part I). Agronomy 9. Soil Sci. Soc. Amer., Madison, WI, USA.

Gunawan, T. (1991). Penerapan Teknik Pengindraan Jauh untuk Menduga. Debit Puncak Menggunakan Karakteristik Lingkungan Fisik DAS. (in Indonesian)

Hann, M.J. \& Morgan, R.P.C. (2006). Evaluation erosion control measures for biorestoration between the time of soil reinstatement and vegetation establishment. Earth Surface Processes and Landforms, 31, 589-597.

Jaya. 2006. Tehnik-tehnik Permodelan Spasial dalam Pengelolaan Sumber daya Alam dan Lingkungan. Fakultas Kehutanan IPB, Bogor. (in Indonesian)

Jetten, V. \& Favis-Mortlock, D. (2006). Modelling
Soil Erosion in Europe.In: J.Boardman, \& J.Possen (Eds), Soil Erosion in Europe (pp.695-716) Chichester, John Wiley \& Sons Ltd, England.

Manik, Y.W, Sumono, Ichwan, N. \& Susanto, E. (2013). Penentuan nilai faktor tanaman jagung dan ubi kayu dengan metode usle dan petak kecil pada tanah Ultisol di Kecamatan Siborongborong Kabupaten Tapanuli Utara. Jurnal Rekayasa Pangan dan Pert., 1(2), 2731. (in Indonesian)

Renard, G.R., Foster, G.A., Weesies, D.K., McCool. \& Yoder, D.C. (1997). Guide Conserv Plan.

Santoso. (2014). Analisis ancaman bencana erosi pada kawasan DAS Beringin Kota Semarang menggunakan Sistem Informasi Geografis. Jurnal Geodesi UNDIP, 3(4), 60-68. (in Indonesian)

Sonapasma, D.M. (2010). Prediksi Erosi dan Perencanaan Konservasi Tanah dan Air pada sub DAS Unda Hulu. Skripsi. Jurusan Tanah. Fakultas Pertanian. Universitas Udayana, Denpasar. (in Indonesian)

Sulistyo, B. (2011). Pengaruh erosivitas hujan yang diperoleh dari rumus yang berbeda terhadap pemodelan erosi berbasisi raster (Studi Kasus di DAS Merawu, Banjar Negara, Jawa Tengah), Jurnal AGRITECH, 31(3), 250-259. (in Indonesian)

Sulistyo, B. (2011). Pemetaan Faktor C yang diturunkan dari berbagai indeks vegetasi data pengindraan sauh sebagai masukan pemodelan erosi di DAS Merawu. J. Manusia dan Lingkungan,18(1), 68-78. (in Indonesian)

Sutanto. (1986). Penginderaan Jauh Jilid 1. Gadjah Mada University Press., Yogyakarta. (in Indonesian)

Tomlin, C. Dana. (2012). GIS and Cartographic Modeling. Esri Press, USA.

Wischmeier, W.H. \& Smith, D.D. (1978). Predicting Rainfall Erosion Losses: A Guide to Conservation Planning.U.S. Dept. Agric., Handb., 537, USA. 